\title{
Optimization of Extrusion Process Using Response Surface Methodology for Producing Squid and Millet Based Extrudate
}

\author{
Viswanth Ganesan ${ }^{1, \#, *(\mathbb{D})}$, Balasundari Subbaiah $\left.{ }^{1, \#} \mathbb{C}^{(}\right)$Nimish Mol Stephen ${ }^{1}{ }^{(}$, \\ Manikandavelu Dhanushkodi ${ }^{2}{ }^{-}$, Rathnakumar Kolandaivadivel $^{3}$, Rajasekar \\ Veeramani $^{4}$ (i)
}

${ }^{1}$ Dr. M.G.R Fisheries College and Research Institute, Department of Fish Processing Technology, Ponneri, TamilNadu, India.

${ }^{2}$ Dr. M.G.R Fisheries College and Research Institute, Department of Aquatic Environment Management, Ponneri, TamilNadu, India.

${ }^{3}$ Tamilnadu Open University, Department of Fish Process Engineering, Chennai, TamilNadu, India.

${ }^{4}$ College of Fisheries Engineering, Department of Aquaculture Engineering, Nagappatinam, TamilNadu, India.

"These authors share the first authorship.

\section{How to cite}

Ganesan, V., Subbaiah, B., Stephen, N.M., Dhanushkodi, M., Kolandaivadivel, R., Veeramani, R. (2022). Optimization of Extrusion Process Using Response Surface Methodology for Producing Squid and Millet Based Extrudate. Turkish Journal of Fisheries and Aquatic Sciences, 22(2), TRJFAS20041. http://doi.org/10.4194/TRJFAS20041

\section{Article History}

Received 17 June 2021

Accepted 20 September 2021

First Online 27 September 2021

Corresponding Author

Tel.: +919677361582

E-mail: viswanth@tnfu.ac.in

\section{Keywords}

Bulk density

Expansion ratio

50 product weight

Heater temperature

Screw speed

\section{Introduction}

Snack has many definitions, Sajilata and Singhal (2005) defined a snack as a small food meal taken in between a regular meal which includes different types of products that may be in forms served as fries, baked confectionaries, pops, vegetable chips, puffs, roasted nuts, and extruded snacks. The snack food industry grows rapidly with a Compound Annual Growth Rate (CAGR) at $7.5 \%$ annually and $89 \%$ of snacks available in the market are non-extruded snack products. Snacks are appreciated by people of all ages, mainly children and teenagers; there is an appeal for the nutritional improvement of this product reported by Ferreira
(2006). The extruded snack products previously were made up of cereal which consists predominantly of high carbohydrate and low protein. In the later part incorporation of meat with cereals was done to produce extrudates which led to the incorporation of fish meat powder in extrusion. Yurjew et al. (1989) stated that the addition of meat to starch ingredients causes thermal instability due to interactions of protein and starch. There were studies carried out by in extrusion technology by incorporating fish meat and fish meat based products to produce extruded snack. Wianecki (2007) reported that the use of proper fish such as lean fish over fatty fish and fresh fish over frozen fish had better extrusion properties. Choudhury and Gautam 
(2003) reported the use of protein sources in extrusion causes a low expansion ratio and increase in hardness of extrudate which leads to limited success in producing fish-based extrudate products commercially. Since the principle of extrusion technology is High- Temperature Short Time (HTST) there will be minimal loss of nutrients. The extrusion process parameters have a significant impact on the properties of an extrudate. Extrusion process parameters should be optimized to obtain an extrudate.

The objective of this study was to determine the optimized extrusion process parameters to produce squid and millet-based extrudate snack products.

\section{Materials and Methods}

This study was conducted at Metro Fish Processing Facility of College of Fisheries Engineering, TNJFU, Nagapattinam, Tamil Nadu, India.

\section{Materials}

The Indian squid (Uroteuthis duvauceli) was purchased from a local fish market and cleaned, cold blanched at $5 \%$ of brine solution, steamed in steam cooker for 15 to 20 minutes, and dried in cabinet drier in $50^{\circ} \mathrm{C}$ to $60^{\circ} \mathrm{C}$ for producing squid powder. Corn flour, finger millet flour, pearl millet flour, and salt were purchased from the local market.

\section{Proximate Composition}

The moisture content of the extruded snack was determined by the standard AOAC method (2006) by placing the sample in a hot air oven at $105^{\circ} \mathrm{C}$ for 5 hours. The nitrogen content of extruded snacks was determined by the Micro Kjeldahl method and multiplying by 6.25 with nitrogen value produces the protein content of extrudate (AOAC, 1995). The crude fat content was determined by the Soxhlet method (AOAC, 1995) using petroleum ether $\left(60^{\circ}-80^{\circ} \mathrm{C}\right)$ as solvent. The ash content of the extrudate was determined by placing the sample in a muffle furnace for 24 hours at temperatures ranging from $500^{\circ} \mathrm{C}$ to $600^{\circ} \mathrm{C}$; the crucible was then cooled in a desiccator, and content in the crucible was weighed (AOAC, 1995).

\section{Extrusion Cooking}

Extrusion was done using a twin-screw extruder (Basics Pvt. Ltd, Kolkata, India). The extruder had two heaters for cooking. The temperature of heater 1 and heater 2 and the speed of twin-screw, feeder, and rotatory cutting blade can be controlled in the extruder. The Finger millet flour at $10 \%$ and pearl millet flour at $10 \%$ are mixed, blended with corn flour $(77 \%, 76 \%, 75 \%$, $74 \%$, and $73 \%)$ and squid powder $(3 \%, 4 \%, 5 \%, 6 \%$, and $7 \%$ ) with $6 \%$ water, sieved for uniform distribution and left for moisture equilibration for an hour.

\section{Determination of Expansion Ratio}

The expansion ratio of extrudate samples was calculated by measuring the diameter of extrudate using a digital vernier caliper (Mitutoyo, Japan). The expansion ratio of the extrudate sample was determined as the diameter of the extrudate to the diameter of the die or orifice (Korkerd, et al, 2016).

\section{Expansion ratio $=$ Diameter of extrudate $/$ Diameter of die or orifice}

\section{Determination of Bulk Density}

The diameters of extrudate samples were measured with a digital vernier caliper (Mitutoyo, Japan), from which the average radius of the extruded snacks was calculated. The shape of the extrudate is assumed to be cylindrical. The total volume is calculated by adding up the length of 20 extrudate samples. The bulk density was determined by the average weight of extrudate to the volume of extrudate samples (Case, et al. 1992).

$$
\begin{gathered}
\text { Bulk density }\left(\mathrm{g} / \mathrm{cm}^{3}\right)=\text { Weight } / \text { Volume of extrudate } \\
\text { samples }
\end{gathered}
$$

\section{Determination of 50 Product Weight}

Fifty product weight of the sample was done by measuring the weight of randomly selected 50 extruded products using a digital weighing balance (Ishtaa, India). Case et al. (1992) stated that the extrudate low fifty product weight tends to have more acceptability.

\section{Experimental Design and Statistical Analysis}

The Response Surface Methodology was used for determining the extrusion process parameters heater 1 temperature $\left(55^{\circ} \mathrm{C}, 60^{\circ} \mathrm{C}\right.$, and $\left.65^{\circ} \mathrm{C}\right)$, heater 2 temperature $\left(120^{\circ} \mathrm{C}, 125^{\circ} \mathrm{C}\right.$, and $\left.130^{\circ} \mathrm{C}\right)$, screw speed (250 rpm, $275 \mathrm{rpm}$, and 300rpm) and inclusion of squid powder $(3 \%, 4 \%, 5 \%, 6 \%$, and $7 \%)$ towards bulk density, expansion ratio, and fifty product weight as responses or variables in the Box-Behnken model (Box and Behnken, 1960). $R^{2}$ and lack of fit test determined for testing the reliability. The surface plots were done based on the effect of two variables over a response for optimization. These studies were carried on Design Expert 11.1.2.0 (STAT - EASE, Inc., USA). Twenty-four runs were conducted based on RSM.

\section{Results and Discussion}

\section{Proximate Composition of Raw Materials}

The proximate compositions of raw materials were given in Table 1 . The crude protein was found to be $84.19 \pm 0.27 \%$ in squid powder, $7.92 \pm 0.22 \%$ in finger 
millet flour, and $10.34 \pm 0.22 \%$ in pearl millet flour. Crude fat was found to be $1.27 \pm 0.33 \%$ in squid powder, $2.53 \pm 0.11 \%$ in finger millet flour, and $4.83 \pm 0.09 \%$ in pearl millet flour. The optimized squid and millet-based extrudate was found to have $19.66 \pm 0.26 \%$ crude protein, $1.98 \pm 0.11 \%$ lipid, $2.64 \pm 0.09 \%$ ash, and $5.73 \pm 0.11 \%$ moisture content. From the proximate composition of raw materials and extrudate, it can be interpreted that crude protein was contributed by the inclusion of squid powder and extrusion cooking removes moisture from extrudate which was blended mixture with additional water added at $6 \%$ level before extrusion. Goes et al. (2015) observed 9\% addition of different fish powders increased protein content $11.85 \pm 0.21 \%$ in Tuna added extrudate, $9.80 \pm 0.49 \%$ in Tilapia added extrudate and $9.21 \pm 0.17 \%$ in Salmon added extrudate. Osman et al. (2017) reported that the shrimp-corn extrudate had a crude protein of $18.8 \%$.

\section{Effect of Process Variables}

The effect of process parameters over the expansion ratio is given in Table 2 . The expansion ratio varied from 3.8611 to 4.603 . The highest expansion ratio was found at $60^{\circ} \mathrm{C}$ of heater 1 temperature, $130^{\circ} \mathrm{C}$ of heater 2 temperature, $300 \mathrm{rpm}$ of screw speed, and $5 \%$ of squid powder inclusion. Lue et al. (1990) stated that optimized expansion ratio is an important parameter for obtaining better sensory quality. Faller et al. (1998) reported that there is a negative relationship between the expansion ratio and hardness of extrudates. Rehrah et al. (2009) also observed a similar negative relationship between the expansion ratio and protein content of the extrudate.

The effect of process parameters over the bulk density is given in Table 2 . The bulk density varied from $1.3543 \mathrm{~g} / \mathrm{cm}^{3}$ to $3.4466 \mathrm{~g} / \mathrm{cm}^{3}$. The highest bulk density was found at $60^{\circ} \mathrm{C}$ of heater 1 temperature, $125^{\circ} \mathrm{C}$ of heater 2 temperature, $275 \mathrm{rpm}$ of screw speed and 5\% of squid powder inclusion. Ding et al. (2020) stated that bulk density plays a major role in packaging and transportation, the higher the bulk density the lower the transportation and packaging cost; higher bulk density leads to less volume of space occupied.

The effect of process parameters over fifty product weight is given in Table 2 . The fifty product weight varied

Table 1. Proximate composition of raw materials

\begin{tabular}{lccccc}
\hline SI.No. & Raw material & Moisture (\%) & Protein (\%) & Lipid (\%) & Ash (\%) \\
\hline 1. & Squid powder & $6.77 \pm 0.11$ & $84.19 \pm 0.27$ & $1.27 \pm 0.33$ & $3.34 \pm 0.28$ \\
2. & Finger millet flour & $5.24 \pm 0.29$ & $7.92 \pm 0.22$ & $2.53 \pm 0.11$ & $1.33 \pm 0.11$ \\
3. & Pearl millet flour & $6.71 \pm 0.25$ & $10.34 \pm 0.22$ & $4.83 \pm 0.09$ & $1.47 \pm 0.18$ \\
4. & Extrudate & $5.73 \pm 0.11$ & $19.66 \pm 0.26$ & $1.98 \pm 0.11$ & $2.64 \pm 0.09$ \\
\hline
\end{tabular}

Table 2. Effect of process parameters on responses

\begin{tabular}{|c|c|c|c|c|c|c|c|}
\hline & Factor 1 & Factor 2 & Factor 3 & Factor 4 & Response 1 & Response 2 & Response 3 \\
\hline Run & $\begin{array}{l}\text { A:Heater } 1 \\
{ }^{\circ} \mathrm{C}\end{array}$ & $\begin{array}{c}\text { B:Heater } 2 \\
{ }^{\circ} \mathrm{C}\end{array}$ & $\begin{array}{c}\text { C:Screw speed } \\
\text { Rpm }\end{array}$ & $\begin{array}{c}\text { D:Squid powder } \\
\%\end{array}$ & $\begin{array}{l}50 \text { Product weight } \\
\text { G }\end{array}$ & Expansion Ratio & $\begin{array}{c}\text { Bulk Density } \\
\mathrm{g} / \mathrm{cm}^{3}\end{array}$ \\
\hline 1 & 60 & 125 & 275 & 3 & $11^{*}$ & 4.108 & 1.7153 \\
\hline 2 & 60 & 125 & 275 & 5 & 12 & 4.125 & 1.9319 \\
\hline 3 & 60 & 125 & 275 & 6 & 12 & 4.189 & 1.9289 \\
\hline 4 & 55 & 120 & 275 & 5 & $11^{*}$ & 4.2701 & 1.6322 \\
\hline 5 & 65 & 120 & 275 & 5 & 13 & 4.451 & 2.49 \\
\hline 6 & 60 & 125 & 275 & 7 & 12 & 4.157 & 1.9304 \\
\hline 7 & 65 & 130 & 275 & 5 & 13 & 4.4384 & 1.5328 \\
\hline 8 & 55 & 130 & 275 & 5 & 13 & 4.3923 & 2.5192 \\
\hline 9 & 60 & 130 & 300 & 5 & $16^{* *}$ & $4.603 * *$ & 1.8911 \\
\hline 10 & 60 & 125 & 275 & 4 & 12 & 4.165 & 1.932 \\
\hline 11 & 60 & 130 & 250 & 5 & $11^{*}$ & 4.221 & 2.5637 \\
\hline 12 & 55 & 125 & 250 & 5 & 12 & 4.3004 & 2.0268 \\
\hline 13 & 60 & 125 & 275 & 5 & 13 & 4.133 & $1.3543^{*}$ \\
\hline 14 & 65 & 125 & 300 & 5 & 13 & 4.563 & 1.8113 \\
\hline 15 & 60 & 120 & 300 & 5 & 14 & 4.4366 & 2.5887 \\
\hline 16 & 55 & 125 & 300 & 5 & 15 & $3.8611^{*}$ & $3.4466^{*}$ \\
\hline 17 & 65 & 125 & 250 & 5 & $11^{*}$ & 4.2519 & 1.9591 \\
\hline 18 & 60 & 120 & 250 & 5 & $11^{*}$ & 4.1861 & 1.8524 \\
\hline 19 & 65 & 125 & 300 & 5 & 14 & 4.465 & 1.9005 \\
\hline 20 & 60 & 120 & 300 & 5 & 15 & 4.549 & 2.4751 \\
\hline 21 & 60 & 125 & 250 & 3 & 11 & 4.1924 & 2.0124 \\
\hline 22 & 65 & 125 & 275 & 3 & 12 & 4.1145 & 1.8546 \\
\hline 23 & 60 & 125 & 300 & 7 & 14 & 4.4265 & 1.9234 \\
\hline 24 & 55 & 120 & 275 & 5 & 12 & 4.1971 & 1.6572 \\
\hline
\end{tabular}

\footnotetext{
${ }^{*}$ represents the lowest value, and ${ }^{* *}$ represents the highest value.
} 
from $11 \mathrm{~g}$ to $16 \mathrm{~g}$. The highest fifty product weight was found at $60^{\circ} \mathrm{C}$ of heater 1 temperature, $130^{\circ} \mathrm{C}$ of heater 2 temperature, $300 \mathrm{rpm}$ of screw speed, and $5 \%$ of squid powder inclusion.

From the ANOVA (Table 3, Table 4 and Table 5), it was observed that the extrusion process parameters were found significant $(P \leq 0.05)$ in overall responses. The lack of fit test was determined to be insignificant $(P \geq 0.05)$ in responses. $R^{2}$ value was found to be 0.8182 in expansion ratio, 0.8085 in bulk density, and 0.8649 in fifty product weight. From the significance test, it can be observed the extrusion parameters and percentage of squid powder inclusion had an impact on the expansion ratio, bulk density, and fifty product weight.

\section{Optimization of Extrusion Process Parameters Using RSM}

The relationship between process parameters (Independent variables) and responses (Dependent variables) are shown in Figure 1, Figure 2, and Figure 3. The optimum process parameters are indicated in Figure 4. For better responses value, the optimum process parameters have been arrived at from RSM. The responses from the predicted values can be verified if the response values from the optimum process parameter are closer to the predicted value. The optimum process parameters were determined as $64.10^{\circ} \mathrm{C}$ heater 1 temperature, $129.98^{\circ} \mathrm{C}$ heater 2

Table 3. Analysis of variance and Regression coefficient for expansion ratio on quadratic model.

\begin{tabular}{|c|c|c|c|c|c|c|}
\hline Source & Sum of square & $\mathrm{df}$ & Mean Square & F-value & P-value & \\
\hline Model & 0.6108 & 13 & 0.0470 & 3.46 & 0.0281 & Significant \\
\hline A-Heater 1 & 0.2251 & 1 & 0.2251 & 16.58 & 0.0022 & \\
\hline B-Heater 2 & 0.0019 & 1 & 0.0019 & 0.1364 & 0.7196 & \\
\hline C-Screw speed & 0.0160 & 1 & 0.0160 & 1.18 & 0.3030 & \\
\hline D-Squid powder & 0.0171 & 1 & 0.0171 & 1.26 & 0.2884 & \\
\hline$A B$ & 0.0070 & 1 & 0.0070 & 0.5137 & 0.4899 & \\
\hline$A C$ & 0.1270 & 1 & 0.1270 & 9.36 & 0.0121 & \\
\hline$A D$ & 0.0071 & 1 & 0.0071 & 0.5241 & 0.4857 & \\
\hline$B C$ & 0.0001 & 1 & 0.0001 & 0.0039 & 0.9517 & \\
\hline$B D$ & 0.0000 & 0 & & & & \\
\hline$C D$ & 0.0063 & 1 & 0.0063 & 0.2574 & 0.6229 & \\
\hline$A^{2}$ & 0.0041 & 1 & 0.0041 & 0.3002 & 0.5958 & \\
\hline$B^{2}$ & 0.1661 & 1 & 0.1661 & 12.24 & 0.0057 & \\
\hline$C^{2}$ & 0.0064 & 1 & 0.0064 & 0.4682 & 0.5094 & \\
\hline$D^{2}$ & 0.0001 & 1 & 0.0001 & 0.0097 & 0.9237 & \\
\hline Lack of Fit & 0.1219 & 6 & 0.0203 & 5.88 & 0.0540 & Not significant \\
\hline$R^{2}$ & 0.8182 & & & & & \\
\hline Adjusted $\mathrm{R}^{2}$ & 0.5818 & & & & & \\
\hline
\end{tabular}

Table 4. Analysis of variance and Regression coefficient for bulk density on quadratic model

\begin{tabular}{|c|c|c|c|c|c|c|}
\hline Source & Sum of Squares & $\mathrm{df}$ & Mean Square & F-value & $p$-value & \\
\hline Model & 3.68 & 13 & 0.2832 & 3.25 & 0.0345 & Significant \\
\hline A-Heater 1 & 1.14 & 1 & 1.14 & 13.04 & 0.0048 & \\
\hline B-Heater 2 & 0.3895 & 1 & 0.3895 & 4.47 & 0.0607 & \\
\hline C-Screw speed & 0.6810 & 1 & 0.6810 & 7.81 & 0.0190 & \\
\hline D-Squid powder & 0.0556 & 1 & 0.0556 & 0.6375 & 04432 & \\
\hline$A B$ & 1.08 & 1 & 1.08 & 12.39 & 0.0055 & \\
\hline$A C$ & 0.6750 & 1 & 0.6750 & 7.74 & 0.0194 & \\
\hline$A D$ & 0.0002 & 1 & 0.0002 & 0.0021 & 0.9644 & \\
\hline$B C$ & 0.4747 & 1 & 0.4747 & 5.44 & 0.0418 & \\
\hline $\mathrm{BD}$ & 0.0000 & 0 & & & & \\
\hline$C D$ & 0.0525 & 1 & 0.0525 & 0.6025 & 0.4556 & \\
\hline$A^{2}$ & 0.1696 & 1 & 0.1696 & 1.94 & 0.1934 & \\
\hline$B^{2}$ & 0.0189 & 1 & 0.0189 & 0.2173 & 0.6511 & \\
\hline$C^{2}$ & 0.5545 & 1 & 0.5545 & 6.36 & 0.0303 & \\
\hline$D^{2}$ & 0.0120 & 1 & 0.0120 & 0.1374 & 0.7186 & \\
\hline Lack of Fit & 0.6946 & 6 & 0.1158 & 2.61 & 0.01863 & Not significant \\
\hline $\mathrm{R}^{2}$ & 0.8085 & & & & & \\
\hline Adjusted $\mathrm{R}^{2}$ & 0.5594 & & & & & \\
\hline
\end{tabular}


Table 5. Analysis of variance and Regression coefficient for 50 product weight on quadratic model

\begin{tabular}{|c|c|c|c|c|c|c|}
\hline Source & Sum of Squares & df & Mean Square & F-value & $p$-value & \\
\hline Model & 41.19 & 13 & 3.17 & 4.93 & 0.0081 & Significant \\
\hline A-Heater 1 & 0.5046 & 1 & 0.5046 & 0.7846 & 0.3965 & \\
\hline B-Heater 2 & 1.25 & 1 & 1.25 & 1.95 & 0.1931 & \\
\hline C-Screw speed & 4.65 & 1 & 4.65 & 7.23 & 0.0228 & \\
\hline D-Squid powder & 0.2848 & 1 & 0.2848 & 0.4428 & 0.5208 & \\
\hline$A B$ & 0.9941 & 1 & 0.9941 & 1.55 & 0.2421 & \\
\hline$A C$ & 0.2947 & 1 & 0.2947 & 0.4582 & 0.5138 & \\
\hline$A D$ & 0.4619 & 1 & 0.4619 & 0.7181 & 0.4166 & \\
\hline $\mathrm{BC}$ & 0.4084 & 1 & 0.4084 & 0.6350 & 0.4440 & \\
\hline BD & 0.0000 & 0 & & & & \\
\hline$C D$ & 0.2137 & 1 & 0.2137 & 0.3322 & 0.5771 & \\
\hline$A^{2}$ & 0.0954 & 1 & 0.0954 & 0.1483 & 0.7083 & \\
\hline$B^{2}$ & 0.3818 & 1 & 0.3818 & 0.5936 & 0.4589 & \\
\hline$C^{2}$ & 1.09 & 1 & 1.09 & 1.70 & 0.2220 & \\
\hline$D^{2}$ & 0.9231 & 1 & 0.9231 & 1.44 & 0.2585 & \\
\hline Lack of Fit & 4.43 & 6 & 0.7386 & 1.48 & 0.3677 & Not significant \\
\hline$R^{2}$ & 0.8649 & & & & & \\
\hline Adjusted $\mathrm{R}^{2}$ & 0.6894 & & & & & \\
\hline
\end{tabular}

temperature, $317.87 \mathrm{rpm}$ screw speed, and $6.56 \%$ inclusion of squid powder. The predicted values of response for optimized extrudate should be $16.5879 \mathrm{~g}$ of fifty product weight, $1.326 \mathrm{~g} / \mathrm{cm}^{3}$ of bulk density, and 5.19665 of expansion ratio. The obtained response values of the optimized extrudate were $16.524 \mathrm{~g}$ of fifty product weight, $1.319 \mathrm{~g} / \mathrm{cm}^{3}$ of bulk density, and 5.108 of expansion ratio. In this study, the response values from the optimum process parameters were found closer to the predicted values reflect the degree of perfection of the optimization process.

\section{Nutritional and Sensory Assessment of Optimized Extruded Snack}

The amino acid composition, and fatty acid composition of optimized squid and millet snack were analyzed. The essential amino acid such as histidine, threonine, lysine, tryptophan, methionine, valine, isoleucine, leucine and phenylalanine were found to be $0.345,0.480,0.418,0.578,0.603,0.957,0.477,0.947$ and $0.581 \mathrm{mg} / 100 \mathrm{mg}$ respectively in squid extrudate. Omana et al. (2010) determined amino acid profile of $10 \%$ ribbon fish and rice based extruded snack 0.1250 , $0.1016,0.1230,0.0816,0.0839,0.1686,0.1123,0.2488$ and $0.1493 \mathrm{~g} / 100 \mathrm{~g}$ of histidine, threonine, lysine, tryptophan, methionine, valine, isoleucine, leucine and phenylalanine respectively. The essential fatty acid such linolenic acid, eicosapentaenoic acid, docosahexaenoic acid and arachidonic acid were found to be $0.98 \%$, $0.42 \%, 0.98 \%$ and $0.18 \%$ respectively of total fatty acid present in optimized extrudate. Ganesan et al. (2017) found that EPA content of $0.062 \%$ in sardine fish extrudate and $0.33 \%$ in lizard fish extrudate and DHA content of $0.053 \%$ in sardine fish extrudate and DHA was not detected in Lizard fish extrudate.

The sensory analysis of optimized squid and millet extrudate was analyzed by panel consisting of 30 semi trained people for analyzing the sensory properties such as appearance, colour, taste, texture, and overall acceptance. The sensory assessment was done in scale of 1 to 5 where 5 was the maximum scale of preference/like. The appearance of optimized squid and millet extruded snack was $4.38 \pm 0.05$, colour was assessed as $4.56 \pm 0.04$, taste was assessed as $4.46 \pm 0.05$, texture was found to be $4.52 \pm 0.04$, and overall acceptance was found as $4.35 \pm 0.04$. Jeyakumari and Rathnakumar (2006) stated that addition of high protein source affects the hardness and crispiness of the extrudate due to interaction of protein and starch. It was also found in the present study that the increase in inclusion of squid powder resulted in less crispiness.

\section{Conclusion}

In this study squid and millet-based extrudate was produced by optimizing extrusion process parameters and percentage inclusion of squid powder. The optimization of the extrusion process parameter added value to the extrudate. The extrusion process parameters such as heater 1 temperature, heater 2 temperature, screw speed, and percentage of squid powder inclusion had a significant $(P \leq 0.05)$ impact on bulk density, expansion ratio, and fifty product weight. The optimum process parameter was determined as $64.10^{\circ} \mathrm{C}$ of heater 1 temperature, $129.98^{\circ} \mathrm{C}$ of heater 2 temperature, screw speed of $317.87 \mathrm{rpm}$, and $6.56 \%$ of inclusion of squid powder.

\section{Ethical Statement}

Not applicable.

\section{Funding Information}

The grant support of their University, Tamil Nadu Dr. J.J. Jayalalithaa Fisheries University (TNJFU). 

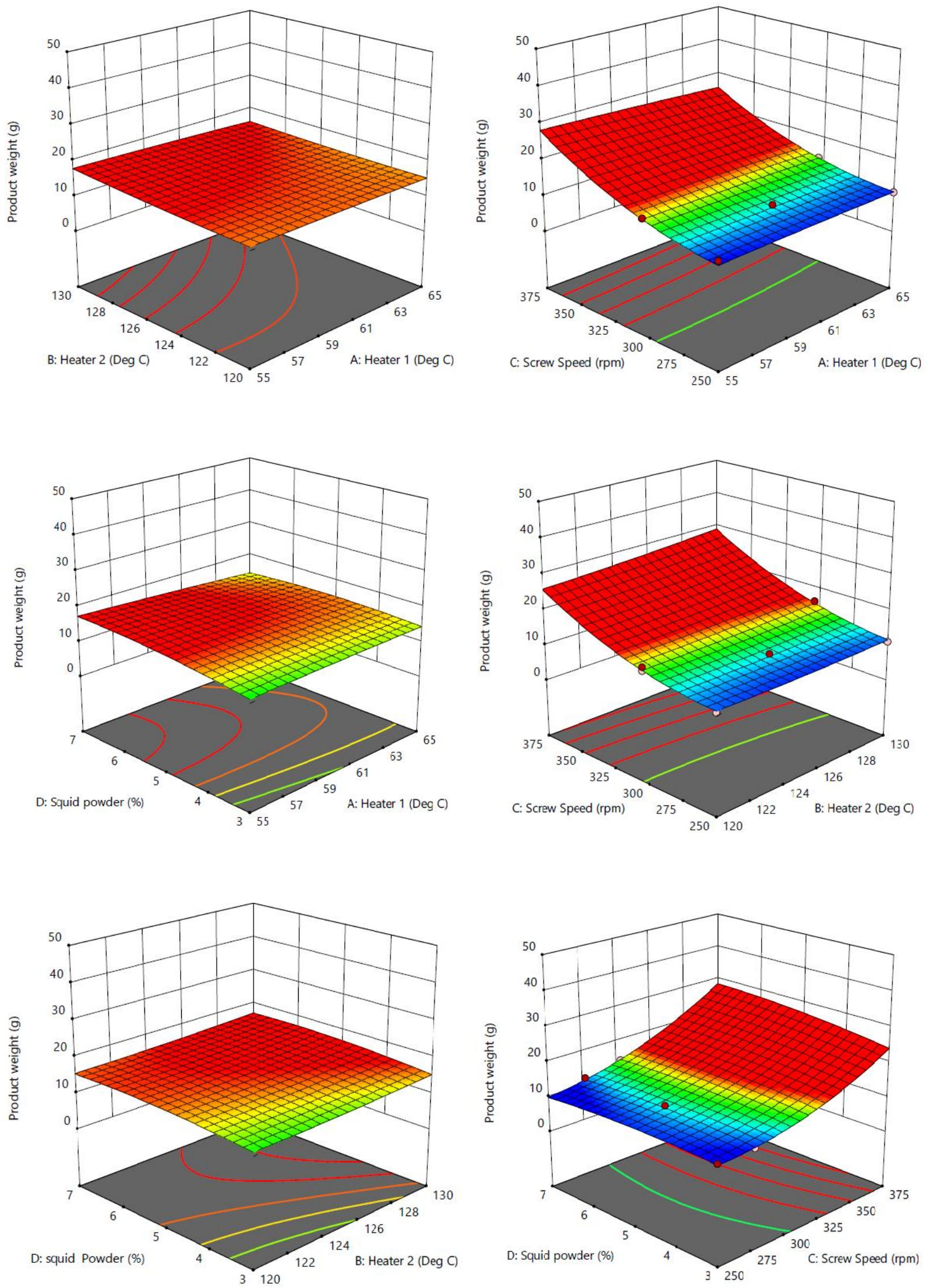

Figure 1. Effect of variables upon 50 product weight response on surface plots. 

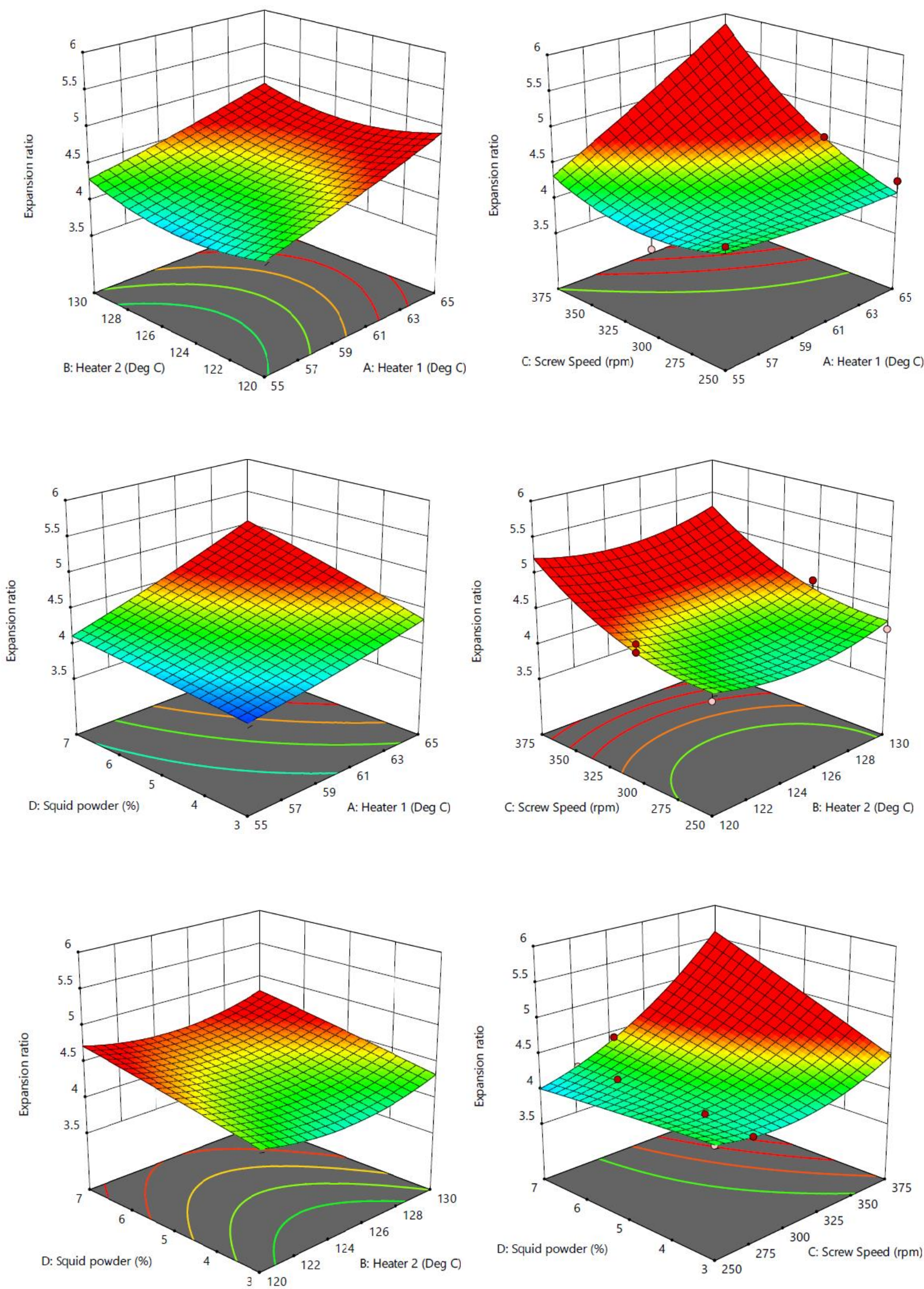

Figure 2. Effect of variables upon expansion ratio response on surface plots. 

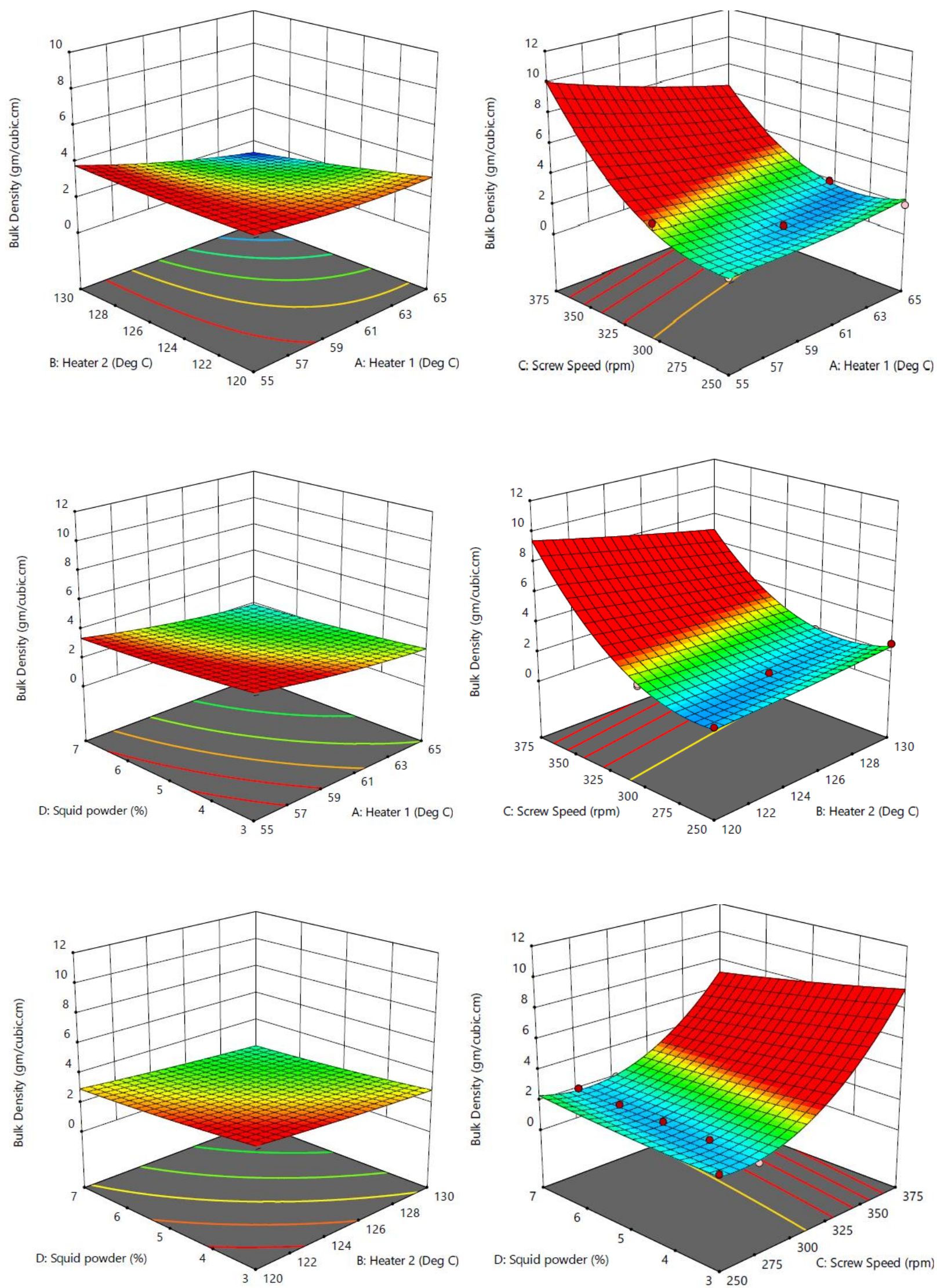

Figure 3. Effect of variables upon expansion ratio response on surface plots. 
Design-Expert Software

Factor Coding: Actual

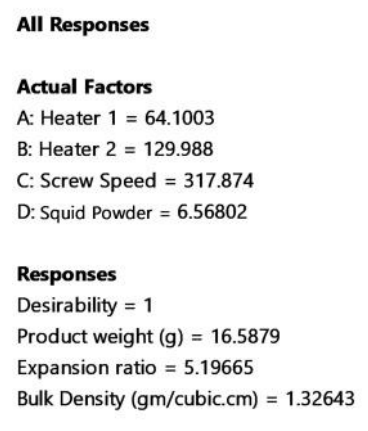

A: Heater 1 (Deg C) B: Heater 2 (Deg C) C: Screw Speed (rpm) D: Squid Powder (\%)

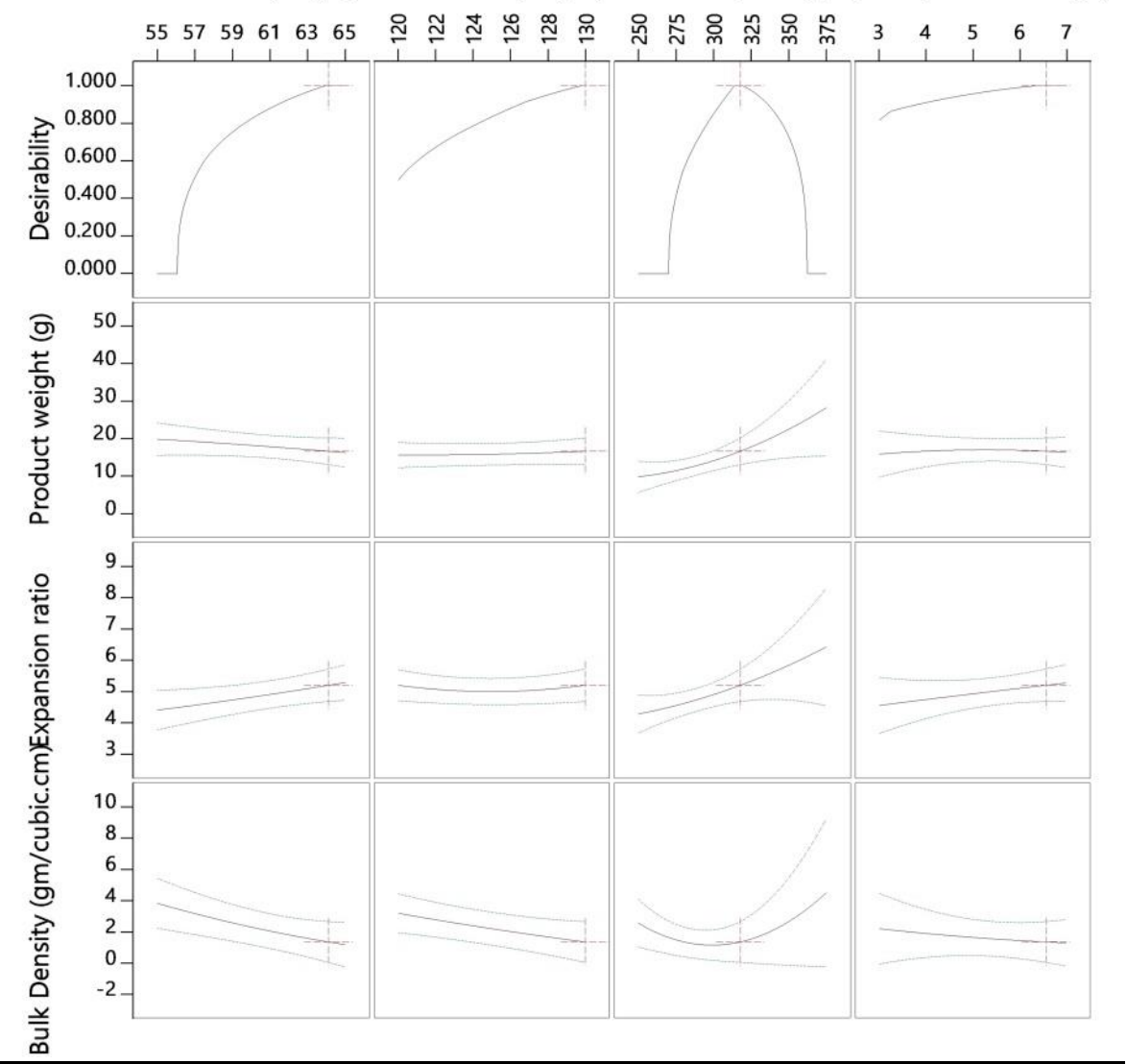

Figure 4. Optimum process parameter overlay graph.

\section{Author Contribution}

First Author: Formal Analysis, Investigation, Methodology, Visualization and Writing -original draft; Second Author: Data Curation and Writing -review and editing; Third Author: writing - review and editing; Fourth Author: Writing review and editing; Fifth Author: Conceptualization, supervision and Sixth Author: Methodology and analysis.

\section{Conflict of Interest}

The author(s) declare that they have no known competing financial or non-financial, professional, or personal conflicts that could have appeared to influence the work reported in this paper.

\section{Acknowledgements}

Dr.P. Karthick Kumar, M.Tech., Ph. D, Assistant Professor, College of Fisheries Engineering.

\section{References}

AOAC. 1995. Official methods of analysis, 16th eds. Association of Official Analytical Chemists, AOAC International, Arlington, VA, USA.
AOAC. 2006. Official methods of analysis, 18th eds. Association of Official Analytical Chemists, AOAC International, Gaithersburg, Maryland, USA.

Box, G.E., Behnken, D.W. 1960. Some new three level designs for the study of quantitative variables. Technometrics. 2(4), 455-475.

Case, S.E., Hamann, D.D., \& Schwartz, S. J. (1992). Effect of starch gelatinization on physical properties of extruded wheat and corn based products. Cereal Chemistry 69 (4): 401-404.

Choudhury, G.S., \& Gautam, A. 2003. Effects of hydrolysed fish muscle on intermediate process variables during twinscrew extrusion of rice flour. LWT Food Science and Technology, 36(7), 667-678.

Ding, H., Li. B., Boiarkina, I., Wilson, D.I., Yu, W., \& Young, B.R. 2020. Effects of Morphology on the Bulk Density of Instant Whole Milk Powder. Foods. 9(8):1024.

Faller, J., \& Klein, B. 1998. Characterization of corn-soy breakfast cereals by generalized procrustes analyses. Cereal Chemistry, 75(6), 904-908.

Ferreira, R.E. (2006). Avaliação de parâmetros do processo de extrusão e do teor de farelo de trigo adicionado em características de "snacks" expandidos de milho (Doctoral Thesis). Universidade Estadual de Campinas, Campinas, $162 \mathrm{f}$.

Goes, E.S.R., Souza, M.L.R., Campelo, D.A.V., Yoshida, G.M., Xavier, T.O., Moura, L.B., Monteiro, A.R.G. 2015. Extruded snacks with the addition of different fish meals. Food Science Technology, 35(4), 683-689. 
Jeyakumari, A., Rathnakumar, K. 2006. Effect of incorporation of frozen stored minced fish on the quality of gelatinized product from rice and maize flour. Fishery Technology, 43, 146-153.

Korkerd, S., Wanlapa, S., Puttanlek, C., Uttapap, D., Rungsardthong, V. 2016. Expansion and functional properties of extruded snacks enriched with nutrition sources from food processing by-products. Journal of Food Science Technology, 53(1), 561-70.

Lue, S., F. Hsieh, Peng, I.C., Huff, H.E. 1990. Expansion of corn extrudates containing dietary fibre: a microstructure study. LWT Food Science and Technology. 23, 165-170.

Omana, D.A., Shamasundar, B.P.K., Howell., Nazlin. 2010. Composition and quality of rice flour-fish mince based extruded products with emphasis on thermal properties of rice flour. Journal of Texture Studies, 41, 190-207.

Osman, K.T., Nalan, G., Kirsi, J., Satu, K. 2017. Development of Extruded Shrimp-Corn Snack Using Response Surface Methodology. Turkish Journal of Fisheries and Aquatic Sciences, 17, 333-343.
Pandi, G., Rathnakumar, K., Velayutham, P., Shakila, R., Anand, S., Arone, B. (2019). Extruded Fish Snack from Low Valued Fatty Fish: An Evaluation of Nutritional and Organoleptic Characteristics. Journal of Coastal Research, 81, 61-64.

Rehrah, D., Ahmedna, M., Goktepe, I., Yu, J. 2009. Extrusion parameters and consumer acceptability of a peanutbased meat analogue. International Journal of Food Science and Technology. 44(10), 2075-2084.

Sajilata, M.G., \& Singhal, R.S. 2005. Specialty Starches for Snack Foods. Carbohydrate Polymers, 59, 131-151.

Wianecki, M. 2007. Evaluation of fish and squid meat applicability for snack food manufacture by indirect extrusion cooking. Acta Scientiarum Polonorum: Technologia Alimentaria, 6P.

Yurjew, V., Likhodziewskaya, I., Zasypkin, D., Alekseev, V., Grinberg, V.Y., Polyakow, V. 1989. Investigation of the microstructure of textured proteins produced by thermoplastic extrusion. Die Nahrung, 33, 823-830. 